\title{
ANALISIS HASIL DRIVE TEST MENGGUNAKAN SOFTWARE GENEX PROBE DAN GENEX ASSISTANT PADA JARINGAN LTE
}

\author{
S.G.Y.P. Putra ${ }^{1}$, P.K. Sudiarta ${ }^{2}$, G. Sukadarmika ${ }^{3}$ \\ ${ }^{1,2,3}$ Program Studi Teknik Elektro, Fakultas Teknik, Universitas Udayana \\ Email : $\underline{\text { sanggede95@gmail.com }}{ }^{1}$, sudiarta@unud.ac.id ${ }^{2}$, sukadarmika@unud.ac.id $^{3}$
}

\begin{abstract}
Abstrak
Pengimplementasian Long Term Evolution (LTE) di Bali mengalami kendala terutama dalam menjaga performansi jaringan yang diakibatkan oleh lonjakan data yang semakin meningkat dan kualitas coverage yang kurang maksimal. Maka perlu dilakukan pemeliharaan jaringan untuk mengetahui kualitas dari suatu jaringan yang dapat dilakukan melalui pengamatan secara real di lapangan dengan pengukuran parameter 4G LTE pada suatu wilayah yang belum optimal. Metode yang digunakan adalah dengan melakukan Drive Test menggunakan software GENEX Probe dan analisa hasil drive test menggunakan software GENEX Assistant. Adapun parameter yang diukur antara lain RSRP, SINR, RSSI, RSRQ, CQI, PCI dan PDCP Throughput yang kemudian dibandingkan dengan standar KPI XL. Hasil dan analisa diperoleh nilai RSRP sebesar 93,36\% $\geq-105 \mathrm{dBm}$, SINR sebesar $91,14 \% \geq 3 \mathrm{~dB}$, PDCP DL Throughput sebesar $92,18 \% \geq 5$ Mbps dan PDC $P$ UL Throughput sebesar $88,73 \% \geq 3$ Mbps yang belum memenuhi standar KPI XL sebesar 95\% diakibatkan oleh faktor variasi obstacle sehingga terjadi area bad spot pada beberapa titik wilayah. Optimalisasi yang dilakukan menggunakan metode mekanikal tilt dengan mengubah tilt antena dari $2^{0}$ menjadi $3^{0}$ pada area bad spot menyebabkan peningkatan performansi RSRP sebesar 3,49\%, SINR sebesar 5,91\%, PDCP Download Throughput sebesar 4,7\% dan PDCP Upload Throughput sebesar 10,73\% dari standar Key Performance Indicator (KPI) XL.
\end{abstract}

Kata Kunci : Drive Test, GENEX Assistant, GENEX Probe, LTE, Mekanikal Tilt

\section{PENDAHULUAN}

Perkembangan teknologi saat ini yang sangat membutuhkan internet sehingga kualitas jaringan telekomunikasi dituntut agar semakin baik khususnya dalam hal kecepatan data. Operator harus peka terhadap keluhan pelanggan yang menginginkan tingginya kualitas akses data dan sinyal yang kuat. User dewasa ini menuntut dan membutuhkan kecepatan, kepastian dan kenyamanan solusi pelayanan, khususnya telekomunikasi data yang dapat diakomodasi oleh kepuasan itu bisa menggembirakan [1].

Untuk itu diperlukan pemeliharaan jaringan untuk mengetahui kualitas jaringan pada suatu wilayah. Pengukuran kualitas jaringan tidak hanya dilakukan pada jaringan LTE namun juga pada jaringan WLAN. Wireless LAN merupakan local area network yang menghubungkan dua komputer atau lebih tanpa menggunakan kabel. Pengukuran pada jaringan WLAN didalam gedung untuk mengetahui kualitas signal level dan throughput [2],[3]. Sedangkan pada jaringan LTE, pengukuran kualitas jaringan dilakukan dengan cara drive test. Drive test adalah kegiatan mengumpulkan data pengukuran kualitas sinyal suatu jaringan yang bertujuan untuk meningkatkan kualitas suatu jaringan. Dalam melakukan drive test diperlukan perlengkapan seperti software pendukung, Mobile Station (MS), Laptop dan Global Positioning System (GPS) [4].

Pada penelitian ini menggunakan software GENEX Probe sebagai software pendukung saat melakukan drive test dan software GENEX Assistant sebagai software analisa hasil dari drive test. Penelitian ini dilakukan dengan mengukur performansi jaringan LTE secara Single Site Verification (SSV) di wilayah Badung yaitu desa Auman dengan rute drive test yang meliputi Jalan Pura Kancing Gumi, Jalan Auman dan Jalan Raya Pura Pucak Mangu.

Sehingga nantinya diperoleh variabel yang dapat diidentifikasi melalui software GENEX Probe dan cara melakukan analisa data menggunakan software GENEX Assistant kemudian dibandingkan dengan standar Key Performance Indicator (KPI) PT. XL Axiata, Tbk. Apabila hasil yang diperoleh tidak sesuai 
dengan standar KPI XL maka selanjutnya dilakukan proses optimalisasi.

\section{KAJIAN PUSTAKA}

\subsection{Pengenalan LTE}

Long Term Evolution (LTE) adalah sebuah nama yang diberikan kepada suatu proyek dalam The Third Generation Partnership Project (3GPP) untuk mengembangkan standar komunikasi bergerak Universal Mobile Telecommunication System (UMTS) dalam mengatasi kebutuhan mendatang. Menurut standar, LTE memberikan kecepatan uplink hingga 50 megabit per detik (Mbps) dan kecepatan downlink hingga 100 Mbps [5].

\subsection{Parameter Pada Drive Test LTE}

Drive test merupakan salah satu bagian pekerjaan dalam optimasi jaringan radio. Drive test bertujuan untuk mengumpulkan informasi jaringan secara real dilapangan [5].

Berikut dibawah ini merupakan mayoritas parameter yang digunakan dalam drive test pada teknologi LTE [5].

\section{RSRP (Reference Signal Received Power)}

Merupakan sinyal LTE power yang diterima oleh user dalam frekuensi tertentu. Parameter ini adalah parameter spesifik pada drive test 4G LTE dan digunakan oleh perangkat untuk menentukan titik handover.

\section{SINR (SI(I+N) (Signal to Noise Ratio))}

SINR adalah merupakan rasio perbandingan antara sinyal utama yang dipancarkan dengan interferensi dan noise yang timbul (tercampur dengan sinyal utama).

\section{RSSI (Received Signal Strength Indicator)}

Merupakan power sinyal yang diterima user dalam rentang frekuensi tertentu termasuk noise dan interferensi (wideband power) [6].

\section{RSRQ (Reference Signal Received Quality)}

Merupakan parameter yang menentukan kualitas dari sinyal yang diterima [6].

\section{CQI (Channel Quality Indicator)}

Merupakan kualitas dari sebuah channel downlink (dari site ke user) dengan kondisi dedicated mode. CQI dapat diperoleh dari user yang melakukan pemberian informasi terhadap site berupa modulasi yang digunakan, code rate, dan efficiency [6].

\section{PCI (Physical Cell ID)}

Merupakan kode identitas fisik tiap cell pada jaringan LTE. Pada dasarnya, setiap cell akan melakukan broadcast informasi mengenai cell id yang dimilikinya agar user mengenali site tersebut [7].

\section{Throughput}

Throughput adalah laju data aktual dari suatu informasi yang ditransfer. Terdapat dua tipe throughput yaitu download dan upload.

\subsection{Metode Mengatasi Permasalahan pada Jaringan LTE}

Beberapa hal berikut direkomendasikan untuk dilakukan antara lain: melakukan elektrikal tilt (nilai tilt diatur secara elektronik), melakukan mekanikal tilt (nilai tilt diatur secara manual dengan menggeser antena sesuai dengan tilt yg diinginkan), mengubah parameter power dan mengajukan penambahan site baru (new site) [8].

\section{a. Metode Tilt Antenna}

Pengukuran tilt dapat mengacu pada Gambar 1 dan rumus berikut:

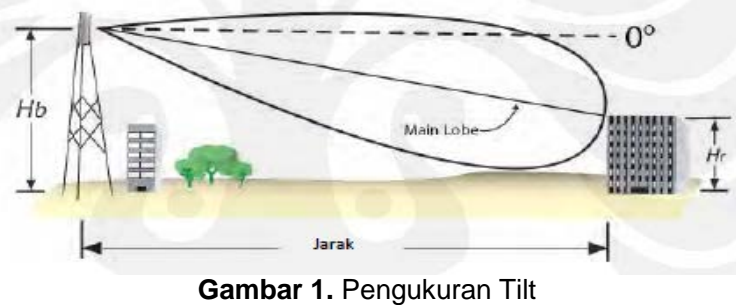

Dari Gambar 1 didapatkan persamaan sebagai berikut :

$$
\begin{array}{ll}
d & =\frac{(H b-H r) / \tan A}{1000} \ldots \ldots \ldots . . . \\
A & =\operatorname{Tan}^{-1} \frac{H b-H r}{(j a r a k \times 1000)} .
\end{array}
$$

Dimana :

$d \quad$ : jarak eNodeB dengan daerah yang dituju (m)

$\mathrm{Hb}$ : Tinggi Antena dari permukaan laut (m)

$\mathrm{Hr}$ : Tinggi Lokasi yang dituju dari permukaan laut (m).

$A \quad$ : Sudut Tilt Antena

Sinyal dari antenna memiliki batas dalam dan batas luar dimana antenna tersebut dapat bekerja secara optimal. Pengukuran batas dalam dan batas luar anten sinyal dari antena dapat mengacu pada Gambar 2 berikut:

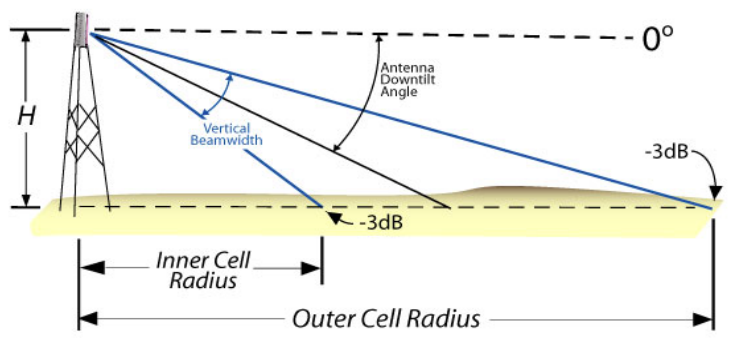

Gambar 2. Batas Inner dan Outer Cell Radius

Inner Radius Distance $=\left(\frac{H / \operatorname{Tan}\left(A+\frac{B W}{2}\right)}{1000}\right)$ 
Outer Radius Distance $=\left(\frac{H / \operatorname{Tan}\left(A-\frac{B W}{2}\right)}{1000}\right) \ldots \ldots$.

Dimana :

$H \quad$ : Tinggi Antena dari permukaan laut (m)

BW : Beam Width Antena

A : Sudut Tilt Antena

\section{c. Mengubah Parameter Power}

Dalam melakukan optimasi jaringan, hal ini perlu dilakukan dengan mengecek parameter yang berhubungan dengan power biasanya, karena masalah ini menyangkut coverage dan quality signal yang diterima oleh user. Jika dalam melakukan tilt antena tidak dapat membantu dalam mengatasi masalah coverage dan quality signal yang diterima oleh user kurang baik maka dengan mengubah parameter power adalah solusinya [8].

\section{d. Penambahan New Site}

Penambahan New Site dilakukan untuk menambah cakupan coverage pada suatu jaringan operator selular dan juga untuk mengurangi adanya blankspot yang mempengaruhi kulitas sinyal di suatu jaringan. Untuk daerah-daerah padat (urban area), operator-operator harus menambahkan site supaya mendapatkan kualitas sinyal dan level sinyal yang baik. Hal ini disebabkan karena area optimasi adalah urban area yang memiliki kerapatan bangunan/ketinggian bangunan yang tinggi sehingga adanya obstacle sangat mempengaruhi kualitas RSRP [8].

\section{METODE PENELITIAN}

Dalam penelitian ini, untuk melakukan drive test, menganalisa hasil drive test dan metode optimalisasi dilakukan dengan empat alur yaitu :

1. Alur pengukuran performansi kualitas jaringan LTE dengan melakukan drive test pada wilayah Auman, Badung dengan mengidentifikasi parameter LTE menggunakan software GENEX Probe.

2. Alur menganalisis hasil drive test dengan dibandingkan dengan KPI XL menggunakan software GENEX Assistant.

3. Alur menganalisis masalah dan menentukan metode optimalisasi yang tepat pada eNodeB Auman dan mendapatkan data sesungguhnya dilapangan.

4. Alur menganalisis hasil drive test setelah proses optimalisasi.

\section{HASIL DAN PEMBAHASAN 4.1 Hasil Pengukuran Drive Test}

Pada penelitian ini, saat melakukan drive test menggunakan perlengkapan untuk menunjang hasil yang diperoleh seperti Gambar 3 dibawah ini:

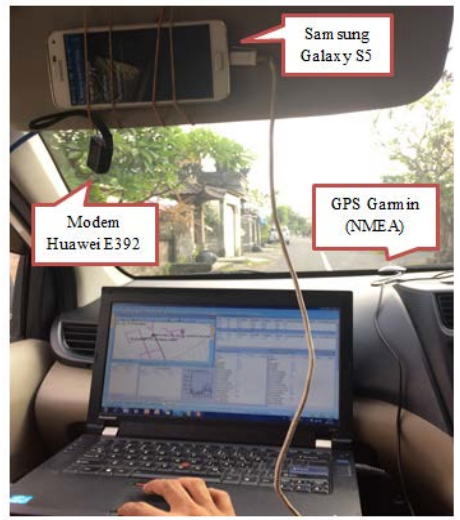

Gambar 3. Melakukan Drive Test pada eNodeB Site ID 610692

Hasil yang diperoleh setelah melakukan drive test menunjukkan bahwa variabel yang dapat diidentifikasi pada jaringan LTE dari software GENEX Probe adalah RSRP, SINR, RSSI, RSRQ, CQI, PCI dan Throughput.

RSRP merupakan kuat sinyal yang diterima UE. RSRP sebanding dengan pengukuran Received Signal Code Power (RSCP) pada teknologi WCDMA dan Rx Level pada teknologi $2 \mathrm{G}$. Kualitas RSRP dapat dilihat pada Tabel 1.

Tabel 1. Kualitas RSRP Pada eNodeB Auman

\begin{tabular}{|c|c|c|c|c|}
\hline $\begin{array}{c}\text { Min } \\
\text { Value } \\
(\mathrm{dBm})\end{array}$ & RSRP Criteria $(\mathrm{dBm})$ & $\begin{array}{l}\text { Max } \\
\text { Value } \\
(\mathrm{dBm})\end{array}$ & $\begin{array}{c}\text { Percentage } \\
\text { (\%) }\end{array}$ & Legend \\
\hline-85 & DL RSRP $(\mathrm{dBm})>=-85$ & Infinity & $22.43 \%$ & \\
\hline-90 & $-90<=$ DL RSRP $(\mathrm{dBm})<-85$ & -85 & $17.69 \%$ & \\
\hline-100 & $-100<=$ DL RSRP $(\mathrm{dBm})<-90$ & -90 & $43.13 \%$ & \\
\hline-105 & $-105<=$ DL RSRP $(\mathrm{dBm})<-100$ & -100 & $10.11 \%$ & \\
\hline-115 & $-115<=$ DL RSRP $(\mathrm{dBm})<-105$ & -105 & $6.64 \%$ & \\
\hline -Infinity & DL RSRP $(\mathrm{dBm})<-115$ & -115 & $0.00 \%$ & \\
\hline \multicolumn{3}{|c|}{ RSRP $>-105 \mathrm{dBm}$} & $93,36 \%$ & $v e t r$ \\
\hline
\end{tabular}

Tabel 1 menunjukkan kualitas RSRP pada eNodeB Auman hanya $93,36 \% \geq(-105) \mathrm{dBm}$ dan dapat dikatakan belum memenuhi standar KPI XL untuk RSRP yaitu 95\% >-105 dBm. Pada kasus ini perlu dicari penyebab belum memenuhinya standar KPI XL nilai RSRP pada eNodeB Auman dan hipotesa penulis untuk hal ini adalah terdapat beberapa area bad spot pada jalur atau rute drive test seperti yang ditunjukkan pada Gambar 4. 


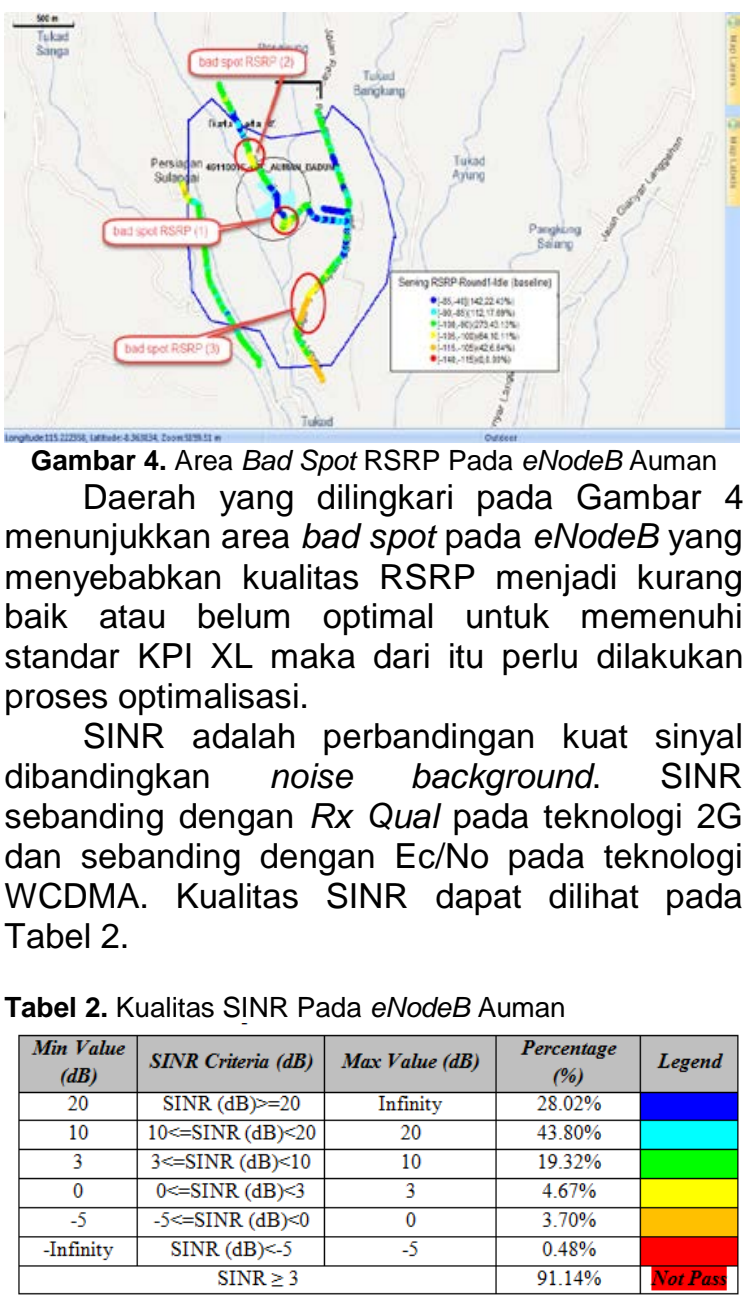

Tabel 2 menunjukkan kualitas SINR pada eNodeB Auman hanya $91,14 \% \geq 3 \mathrm{~dB}$ dan dapat dikatakan belum memenuhi standar KPI XL untuk SINR yaitu 95\% $\geq 3 \mathrm{~dB}$. Pada kasus ini perlu dicari penyebab kurang baiknya SINR pada eNodeB Auman dan hipotesa penulis untuk hal ini adalah terdapat beberapa area bad spot pada jalur atau rute drive test seperti yang ditunjukkan pada Gambar 5.

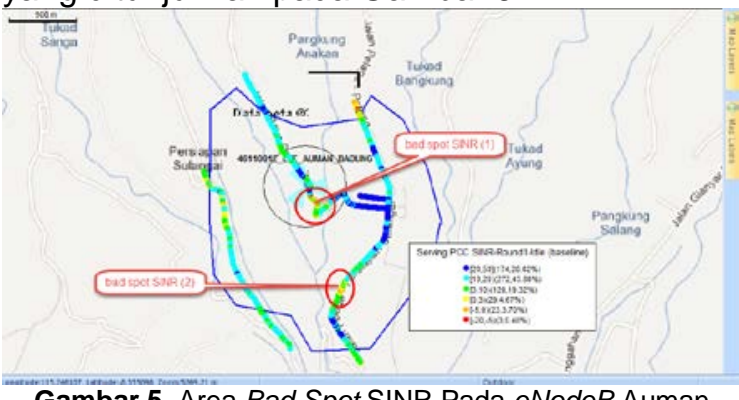

Gambar 5. Area Bad Spot SINR Pada eNodeB Auman

Daerah yang dilingkari pada Gambar 5 menunjukkan area bad spot pada eNodeB yang menyebabkan kualitas SINR kurang baik atau belum optimal untuk memenuhi standar KPI XL maka dari itu perlu dilakukan proses optimalisasi.
RSSI Merupakan power sinyal yang diterima user dalam rentang frekuensi tertentu termasuk noise dan interferensi (disebut juga wideband power). Kualitas RSSI dapat dilihat pada Tabel 3.

Tabel 3. Kualitas RSSI Pada eNodeB Auman

\begin{tabular}{|c|c|c|c|c|}
\hline $\begin{array}{c}\text { Min Value } \\
(\mathrm{dB})\end{array}$ & RSSI Criteria $(\mathrm{dB})$ & $\begin{array}{c}\text { Max Value } \\
(\mathrm{dB})\end{array}$ & $\begin{array}{c}\text { Percentage } \\
(\%)\end{array}$ & Legend \\
\hline-70 & RSSI $(\mathrm{dB})>-70$ & Infinity & $88.04 \%$ & \\
\hline-80 & $-80<=\mathrm{RSSI}(\mathrm{dB})<-70$ & -70 & $11.17 \%$ & \\
\hline-90 & $-90<=\mathrm{RSSI}(\mathrm{dB})<-80$ & -80 & $0.79 \%$ & \\
\hline-110 & $-110<=\mathrm{RSSI}(\mathrm{dB})<-90$ & -90 & $0.00 \%$ & \\
\hline- Infinity & RSSI $(\mathrm{dB})<-110$ & -110 & $0.00 \%$ & \\
\hline
\end{tabular}

Tabel 3 menunjukkan kualitas RSSI pada hasil drive test eNodeB Auman yang dapat dikatakan normal karena persentase jumlah data sudah mencapai $100 \%>-90 \mathrm{~dB}$ dimana lebih dominan pada rentang nilai $>-70 \mathrm{~dB}$ sebesar $88.04 \%$. Oleh sebab itu, maka untuk kualitas RSSI sudah baik.

RSRQ merupakan parameter yang menentukan kualitas dari sinyal yang diterima. RSRQ membantu sistem dalam proses handover di mana RSRQ dapat meranking performansi kandidat sel dalam proses cell selection - reselection dan handover berdasarkan kualitas sinyal yang diterima. Kualitas RSRQ dapat dilihat pada Tabel 4.

Tabel 4. Kualitas RSRQ Pada eNodeB Auman

\begin{tabular}{|c|c|c|c|c|}
\hline $\begin{array}{c}\text { Min Value } \\
(d B)\end{array}$ & RSRQ Criteria $(d B)$ & $\begin{array}{c}\text { Max Value } \\
(d B)\end{array}$ & $\begin{array}{c}\text { Percentage } \\
(\%)\end{array}$ & Legend \\
\hline-6 & RSRQ $(\mathrm{dB})>=-6$ & Infinity & $28.03 \%$ & \\
\hline-9 & $-9<=\mathrm{RSRQ}(\mathrm{dB})<-6$ & -6 & $52.16 \%$ & \\
\hline-11 & $-11<-\mathrm{RSRQ}(\mathrm{dB})<-9$ & -9 & $17.53 \%$ & \\
\hline-14 & $-14<=\mathrm{RSRQ}(\mathrm{dB})<-11$ & -11 & $2.28 \%$ & \\
\hline- Infinity & RSRQ $(\mathrm{dB})<-14$ & -14 & $0.00 \%$ & \\
\hline
\end{tabular}

Tabel 4 menunjukkan kualitas RSRQ pada hasil drive test eNodeB Auman dimana data >$11 \mathrm{~dB}$ mencapai $97,72 \%$ dan jumlah persentase data mencapai $100 \%$. Oleh sebab itu, maka untuk kualitas RSRQ sudah baik dan normal.

CQI merupakan kualitas dari sebuah channel downlink (dari site ke user) dengan kondisi dedicated mode (pada LTE, user melakukan download data). CQI dapat diperoleh dari user yang melakukan pemberian informasi terhadap site berupa modulasi yang digunakan, code rate, dan efficiency. Kualitas CQI dapat dilihat pada Tabel 5.

Tabel 5. Kualitas CQI Pada eNodeB Auman

\begin{tabular}{|c|c|c|c|}
\hline Min Value & CQI & Max Value & Percentage (\%) \\
\hline 10 & $10<=$ CQI Value $<15$ & 58 & $58.00 \%$ \\
\hline 5 & $5<=$ CQI Value $<10$ & 48 & $41.00 \%$ \\
\hline 3 & $3<=$ CQI Value $<5$ & 1 & $1.00 \%$ \\
\hline 0 & $0<=$ CQI Value $<3$ & 0 & $0.00 \%$ \\
\hline
\end{tabular}

Berdasarkan Tabel 5 menunjukkan kualitas CQI pada eNodeB Auman dimana data pada rentang nilai $>10-15$ lebih dominan 
dengan persentase sebesar $58.00 \%$ dan nilai pada rentang 5 - 10 dengan maksimal nilai 48 hanya mendominasi sebesar $41.00 \%$ sedangkan nilai pada rentang 3 - 5 dengan maksimal nilai 1 mendominasi hanya sebesar $1.00 \%$. Jadi dengan rentang nilai $10-15$ dengan maksimal nilai 58 yang lebih mendominasi distribusi CQI dapat dikatakan bahwa kualitas CQI normal dengan persentase jumlah data sudah mencapai 100\%.

$\mathrm{PCl}$ Merupakan kode identitas fisik tiap cell pada jaringan LTE. Pada dasarnya, setiap cell akan melakukan broadcast informasi mengenai cell ID yang dimilikinya agar user mengenali site tersebut. Untuk mengetahui $\mathrm{PCl}$ yang melayani UE pada setiap titik area dapat dilihat pada Gambar 6.

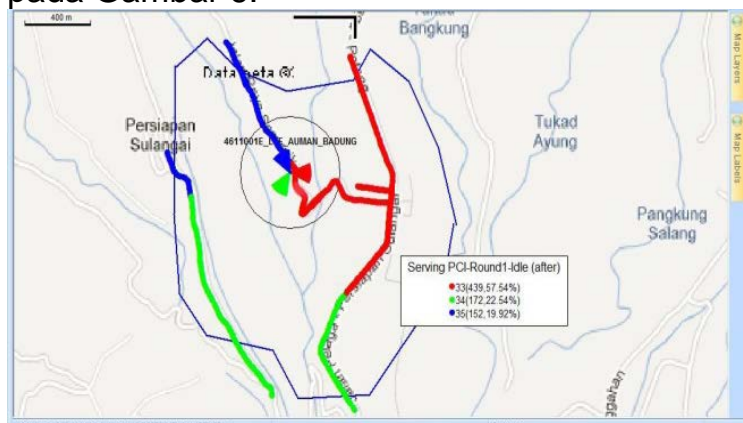

Gambar 6. Data PCI (Physical Cell ID) yang melayani User Equipment pada setiap titik area

Gambar 6 merupakan data logfile hasil drive test yang diexport menggunakan software GENEX Assistant dari layanan eNodeB Auman yang terdiri dari $\mathrm{PCl} 33, \mathrm{PCl} 34$, dan $\mathrm{PCl} 35$. Pada pengukuran yang melewati Jalan Pura Kancing Gumi, Jalan Auman dan Jalan Raya Pura Pucak Mangu untuk PCl yang melayani user equipment yang tercatat pada logfile, persentase $\mathrm{PCl} 33$ yang berwarna merah melayani area sebesar 57,54\%, PCl 34 yang berwarna hijau melayani area sebesar 22,54\% dan $\mathrm{PCl} 35$ yang berwarna biru melayani area sebesar 19,92\%.

Throughput adalah laju data aktual dari suatu informasi yang ditransfer. Selain itu, throughput juga dapat diartikan dengan jumlah informasi yang berhasil dikirim per satuan waktu. Terdapat dua tipe throughput yaitu download dan upload. Kualitas download dan upload throughput dapat dilihat pada Tabel 6 dan Tabel 7.

Tabel 6. Kualitas DL Throughput Pada eNodeB Auman

\begin{tabular}{|c|c|c|c|c|}
\hline $\begin{array}{c}\text { Min Value } \\
\text { (Mpps) }\end{array}$ & DL Throughput (Mbps) & $\begin{array}{c}\text { Max Value } \\
\text { (Mpps) }\end{array}$ & $\begin{array}{c}\text { Percentage } \\
(\%)\end{array}$ & Legend \\
\hline 30 & DL Throughput (Mbps) $>=30$ & Infinity & $0.00 \%$ & \\
\hline 10 & $10<=$ DL Throughput (Mbps $<30$ & 30 & $74.71 \%$ & \\
\hline 5 & $5<=$ DL Throughput (Mbps) $<10$ & 10 & $17.47 \%$ & \\
\hline 3 & $3<=$ DL Throughput (Mpss $<5$ & 5 & $2,68 \%$ & \\
\hline 0 & $0<$ DL Throughput (Mbps) $<3$ & 3 & $2.95 \%$ & \\
\hline
\end{tabular}

Tabel 6 menunjukkan kualitas download throughput secara keseluruhan pada jaringan LTE XL hasil drive test dapat dikatakan belum baik atau belum optimal karena nilai download throughput untuk hasil drive test tersebut hanya $92,18 \% \geq 5$ Mbps belum memenuhi standar KPI $\mathrm{XL}$ untuk download throughput yaitu $95 \% \geq 5$ Mbps. Dan tercatat juga, terdapat alokasi warna merah yang dimana artinya kualitas buruk dari download throughput sebesar $2.95 \%$ pada eNodeB Auman maka dari itu perlu dilakukan proses optimalisasi.

Tabel 7. Kualitas UL Throughput Pada eNodeB Auman

\begin{tabular}{|c|c|c|c|c|}
\hline $\begin{array}{c}\text { Min Value } \\
\text { (Mbps) }\end{array}$ & UL Throughput (Mbps) & $\begin{array}{c}\text { Max Value } \\
\text { (Mbps) }\end{array}$ & Percentage (\%) & Legend \\
\hline 15 & UL Throughput (Mbps) $>=15$ & Infinity & $45.37 \%$ & \\
\hline 10 & $10<=$ UL Throughput (Mbps) $<15$ & 15 & $22.42 \%$ & \\
\hline 5 & 5<=UL Throughput (Mbps) $<10$ & 10 & $16.64 \%$ & \\
\hline 3 & $3<=$ UL Throughput (Mbps) $<5$ & 5 & $4.30 \%$ & \\
\hline 0 & 0<UL Throughput (Mbps) $<3$ & 3 & $11.20 \%$ & \\
\hline
\end{tabular}

Tabel 7 menunjukkan kualitas upload throughput secara keseluruhan pada jaringan LTE XL hasil drive test dapat dikatakan belum baik atau belum optimal karena nilai upload throughput untuk hasil drive test tersebut hanya $88,73 \% \geq 3 \mathrm{Mbps}$ belum memenuhi standar KPI $\mathrm{XL}$ untuk upload throughput yaitu $95 \% \geq 3$ Mbps. Dan tercatat juga, terdapat alokasi warna merah yang dimana artinya kualitas buruk dari upload throughput sebesar $11.20 \%$ pada eNodeB Auman dapat dibilang cukup besar maka dari itu perlu dilakukan proses optimalisasi.

\subsection{Pembahasan}

Pada proses optimalisasi dilakukan dengan metode mekanikal tilt. Metode mekanikal tilt dipilih karena luas coverage antena yang kurang baik sehingga menyebabkan beberapa titik jalan terjadi area bad spot. Selain itu, metode ini dipilih karena pada pihak provider XL belum menyediakan RET (Remote Electrical Tilt) pada eNodeB yang terletak di daerah sub urban dimana user/pengguna nya tidak terlalu padat seperti daerah urban atau perkotaan.

Untuk metode elektrikal tilt hanya tersedia pada eNodeB yang terletak pada daerah urban atau perkotaan dimana aktifitas user yang sangat padat sehingga pada saat terjadinya 
daerah bad spot atau kualitas parameter LTE yang buruk dapat segera tertangani dengan menggunakan Remote Electrical Tilt (RET) melalui suatu program tanpa harus turun ke lapangan. Perubahan tilt antena dapat dilihat pada Tabel 8

Tabel 8. Before dan After Tilt Antena pada Site ID 610692

\begin{tabular}{|c|c|c|c|c|c|c|c|c|c|}
\hline \multirow{2}{*}{ Site Name } & \multirow{2}{*}{ CellID } & \multirow{2}{*}{ Heigh } & \multicolumn{3}{|c|}{ Before } & \multicolumn{3}{|c|}{ After } & \multirow[t]{2}{*}{ Ant Type } \\
\hline & & & \begin{tabular}{|l|} 
Dir \\
\end{tabular} & Mech & Elec & Dir & Mech & Elec & \\
\hline 4511001E_LTE_ATMAAN_BADCNG & 4 & 38 & 90 & 2 & 0 & 90 & 3 & 0 & $\begin{array}{l}\text { TONGYU- } \\
\text { TRIPLIBAND- } \\
2315190\end{array}$ \\
\hline 46110018_LIF_ACMAAN_BADCXYG & 2 & 38 & 220 & 2 & 0 & 210 & 3 & 0 & $\begin{array}{c}\text { TONGYU- } \\
\text { TRPLIBAAND- } \\
2315190\end{array}$ \\
\hline 45110018_LTE_ACMAAN_BADCNGG & 6 & 38 & 330 & 2 & 0 & 330 & 3 & 0 & $\begin{array}{l}\text { TONGYY- } \\
\text { TRPLEBAND- } \\
2311190\end{array}$ \\
\hline
\end{tabular}

Berdasarkan Tabel 8, diperoleh hasil perubahan yang harus dilakukan pada mekanikal tilt adalah sebesar $3^{0}$ dimana awalnya adalah $2^{0}$. Solusi ini didapatkan sesuai perhitungan secara teori cakupan coverage eNodeB Site ID 610692.

eNodeB dengan Site ID 610692 :

- Altitude = 33 meter

- Tinggi Antena = 30 meter $(\mathrm{Hb}=62 \mathrm{~m})$

- $\quad$ Altitude Blindspot = 35 meter

- $\quad$ Tinggi Bangunan sekitar Blindspot $=15$ meter $(\mathrm{Hr}=50 \mathrm{~m})$

- $\quad$ Mekanikal Tilt $=3^{0}(A=3)$ Elektrikal Tilt $=0^{0}$

- Vertikal Beamwidth $=4^{0}$ (TONGYU TRIPLEBAND-2315190)

Jangkauan antena eNodeB Site ID 610692 :

$$
\begin{aligned}
-\quad \text { Jarak Main Beam } & =\left[\frac{(\mathrm{Hb}-\mathrm{Hr})}{\frac{\tan \mathrm{A}}{1000}}\right] \ldots \ldots \ldots . . \\
& =\left[\frac{(62-50)}{\frac{\tan 3}{1000}}\right] \ldots \ldots \ldots \ldots \\
& =0,229 \mathrm{~km} \ldots \ldots \ldots
\end{aligned}
$$

- $\quad$ Inner Radius Coverage $=\frac{(\mathrm{Hb}-\mathrm{Hr})}{\tan \left(\mathrm{A}+\frac{\mathrm{BW}}{2}\right)} \ldots$

$$
\begin{aligned}
& =\frac{(62-50)}{\tan \left(3+\frac{4}{2}\right)} \ldots \ldots \ldots \ldots . . \\
& =137,160 \text { meter... }
\end{aligned}
$$

Perhitungan secara teori menunjukkan bahwa perubahan dari mekanikal tilt dapat menambah cakupan coverage dari antena dengan memperbesar tilt antena tersebut. Coverage yang kurang baik berjarak 623 meter dari letak eNodeB maka didapatkannya perubahan mekanikal tilt sebesar $3^{0}$ diperkuat dengan perhitungan secara teori sebagai berikut :

- $\quad$ Outer Radius Coverage eNodeB dengan Site ID 610692 :

$$
\begin{aligned}
\text { Tilt } & =\tan ^{-1}\left[\frac{62-50}{623}\right]^{+} \frac{4}{2} . \\
& =1,10+2 \ldots \ldots \ldots .
\end{aligned}
$$

\begin{tabular}{|c|c|c|c|c|}
\hline $\begin{array}{c}\text { Min } \\
\text { Value } \\
(d B m)\end{array}$ & $R S R P$ Criteria $(\mathrm{dBm})$ & $\begin{array}{c}\text { Max } \\
\text { Value } \\
(\mathrm{dBm})\end{array}$ & $\begin{array}{c}\text { Percentage } \\
\text { (\%) }\end{array}$ & Legend \\
\hline-85 & DL RSRP $(\mathrm{dBm})>=-85$ & Infinity & $33.29 \%$ & \\
\hline-90 & $-90<=$ DL RSRP $(\mathrm{dBm})<-85$ & -85 & $19.13 \%$ & \\
\hline-100 & $-100<=$ DL RSRP $(\mathrm{dBm})<-90$ & -90 & $39.32 \%$ & \\
\hline-105 & $-105<=$ DL RSRP $(\mathrm{dBm})<-100$ & -100 & $5.11 \%$ & \\
\hline-115 & $-115<=$ DL RSRP $(\mathrm{dBm})<-105$ & -105 & $3.15 \%$ & \\
\hline -Infinity & DL RSRP $(\mathrm{dBm})<-115$ & -115 & $0.00 \%$ & \\
\hline \multicolumn{3}{|c|}{ RSRP $>-105 \mathrm{dBm}$} & $96,85 \%$ & Pass \\
\hline
\end{tabular}

$$
=3,1=3^{0}
$$

Kualitas RSRP setelah optimalisasi dapat dilihat pada Tabel 9.

Tabel 9. Kualitas RSRP Setelah Optimalisasi

Tabel 9 menunjukkan bahwa kualitas RSRP jaringan LTE XL di Auman, Badung setelah dilakukan optimasi mengalami peningkatan sehingga dapat memenuhi standar

\begin{tabular}{|c|c|c|c|c|}
\hline $\begin{array}{c}\text { Min Value } \\
\text { (dB) }\end{array}$ & SINR Criteria $(\mathrm{dB})$ & $\begin{array}{c}\text { Max Value } \\
\text { (dB) }\end{array}$ & $\begin{array}{c}\text { Percentage } \\
(\%)\end{array}$ & Legend \\
\hline 20 & $\operatorname{SINR}(d B)>=20$ & Infinity & $29.66 \%$ & \\
\hline 10 & $10<=\operatorname{SINR}(d B)<20$ & 20 & $51.93 \%$ & \\
\hline 3 & $3<=\operatorname{SINR}(\mathrm{dB})<10$ & 10 & $15.45 \%$ & \\
\hline 0 & $0<=\operatorname{SINR}(\mathrm{dB})<3$ & 3 & $2.05 \%$ & \\
\hline-5 & $-5<=\operatorname{SINR}(\mathrm{dB})<0$ & 0 & $0.91 \%$ & \\
\hline -Infinity & SINR $(\mathrm{dB})<-5$ & -5 & $0.00 \%$ & \\
\hline \multicolumn{3}{|c|}{ SINR $\geq 3$} & $97.05 \%$ & Pass \\
\hline
\end{tabular}
KPI XL yaitu sebesar 96,85\% $\geq-105 \mathrm{dBm}$ dari sebelum optimalisasi sebesar 93,36\% $\geq-105$ $\mathrm{dBm}$ dimana standar KPI XL untuk RSRP yaitu 95\% > -105 dBm.

Kualitas SINR setelah optimalisasi dapat dilihat pada Tabel 10.

Tabel 10. Kualitas SINR Setelah Optimalisasi

Tabel 10 menunjukkan bahwa kualitas SINR jaringan LTE XL di Auman, Badung setelah dilakukan optimalisasi mengalami peningkatan sehingga dapat memenuhi standar KPI XL sebesar $97,05 \% \geq 3 \mathrm{~dB}$ dari sebelum

\begin{tabular}{|c|c|c|c|c|}
\hline $\begin{array}{c}\text { Min Value } \\
\text { (Mbps) }\end{array}$ & DL Throughput (Mbps) & \begin{tabular}{|c|} 
Max Value \\
(Mbps)
\end{tabular} & $\begin{array}{c}\text { Percentage } \\
\text { (\%) }\end{array}$ & Legend \\
\hline 30 & DL Throughput $(\mathrm{Mbps})>=30$ & Infinity & $28.92 \%$ & \\
\hline 10 & $10<=\mathrm{DL}$ Throughput $(\mathrm{Mbps})<30$ & 30 & $57.54 \%$ & \\
\hline 5 & $5<=\mathrm{DL}$ Throughput $(\mathrm{Mbps})<10$ & 10 & $10.42 \%$ & \\
\hline 3 & $3<=$ DL Throughput $(\mathrm{Mbps})<5$ & 5 & $1.14 \%$ & \\
\hline 0 & $0<\mathrm{DL}$ Throughput $(\mathrm{Mbps})<3$ & 3 & $0.78 \%$ & \\
\hline \multicolumn{3}{|c|}{ DL Throughput $>5 \mathrm{Mbps}$} & $96,88 \%$ & Pass \\
\hline
\end{tabular}
optimalisasi sebesar $91,14 \%>3 \mathrm{~dB}$ dimana standar KPI XL untuk SINR yaitu 95\% $\geq 3 \mathrm{~dB}$.

Kualitas Download Throughput dan Upload Throughtput setelah optimalisasi dapat dilihat pada Tabel 11 dan Tabel 12.

Tabel 11. Kualitas Download Throughput Setelah Optimalisasi

Tabel 11 menunjukkan bahwa kualitas download throughput jaringan LTE XL di Auman, Badung setelah dilakukan optimalisasi mengalami peningkatan sehingga dapat 
memenuhi standar KPI XL sebesar $96,88 \% \geq 3$ Mbps dari sebelum optimalisasi sebesar $92,18 \% \geq 5$ Mbps dimana standar KPI XL untuk download throughput yaitu $95 \% \geq 5$ Mbps.

Tabel 12. Kualitas Upload Throughput Setelah Optimalisasi

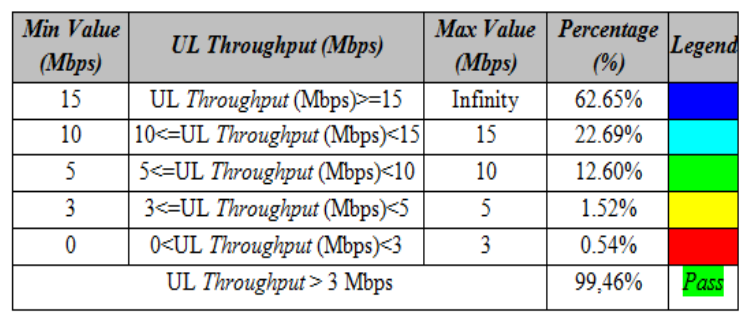

Tabel 12 menunjukkan bahwa kualitas upload throughput jaringan LTE XL di Auman, Badung setelah dilakukan optimalisasi mengalami peningkatan sehingga dapat memenuhi standar KPI XL sebesar 99,46\% $\geq 3$ Mbps dari sebelum optimalisasi sebesar $88,73 \% \geq 3$ Mbps dimana standar KPI XL untuk upload throughput yaitu $95 \% \geq 3$ Mbps.

\section{SIMPULAN} berikut :

Simpulan dari penelitian ini adalah sebagai

1. Pada analisa pengukuran drive test menggunakan software GENEX Probe untuk menunjang saat melakukan pengukuran nilai parameter LTE dalam prakteknya, GENEX Probe dapat mengidentifikasi varibel jaringan LTE yaitu RSRP, SINR, RSSI, RSRQ, CQI, PCI dan Throughput.

2. Pada analisa hasil drive test menggunakan software GENEX Assistant pada site ID 610692 dilakukan dengan cara mengexport logfile yang sudah disimpan dari pengukuran drive test menggunakan software GENEX Probe. Hasil yang diperoleh terdapat area bad spot pada beberapa titik di eNodeB site ID 610692. Hal ini menyebabkan kualitas nilai RSRP, SINR dan Throughput yang kurang baik sehingga tidak memenuhi standar KPI $\mathrm{XL}$ maka dari itu perlu dilakukan proses optimalisasi pada area tersebut. Optimalisasi yang dilakukan adalah mengubah tilt antena dengan metode mekanikal tilt pada eNodeB site ID 610692

3. Perbandingan data hasil drive test yang diperoleh dengan target KPI XL sudah memenuhi standar. Hasil yang diperoleh setelah dilakukan proses optimalisasi melalui metode mekanikal tilt dengan mengubah tilt antena dari $2^{0}$ menjadi $3^{0}$ sehingga menyebabkan peningkatan performansi RSRP sebesar 3,49\%, SINR sebesar 5,91\%, PDCP Download Throughput sebesar $4,7 \%$ dan PDCP Upload Throughput sebesar 10,73\% sehingga sesuai dengan standar KPI XL.

\section{DAFTAR PUSTAKA}

[1] Kuncoro, T, Sirait, Sari. 2013. Analisa Performansi Jaringan 3G. Studi Kasus : Indosat Bandung,Jurnal Asitron.4(1).63-71

[2] AAN. Agung Indra Prasetya, N. Gunantara, P.K. Sudiarta. 2017. Analisis Propagasi Indoor WLAN $802.11 \mathrm{~g}$ pada Gedung Dishubkominfo Kabupaten Badung. E-Journal SPEKTRUM Vol. 4, No. 2 Desember 2017.

[3] N Gunantara, P K Sudiarta, AAN A I Prasetya, A Dharma, and I N Gde Antara. 2017. Measurements of the Received Signal Level and Service Coverage Area at the IEEE 802.11 Access Point in the Building. International Conference on Sustainable Development and Green Technology SDGT 2017. Nanhua University, Taiwan, November 24-26.

[4] R. Yanuari, P.K. Sudiarta, N. Gunantara. 2015. Analisa Kualitas Sinyal Jaringan GSM Pada Menara Rooftop dengan Membandingkan Aplikasi Metode Drive Test antara TEMS Investigation 8.0.3 dengan G-Nettrack Pro. E-Journal SPEKTRUM Vol. 2, No. 4 Desember 2015.

[5] Pramulia, Dedy. 2015. Analisis Pengaruh Jarak Antara User Equipment Dengan eNodeB Terhadap Nilai RSRP (Reference Signal Received Power) Pada Teknologi LTE $900 \mathrm{MHz}$. E-Journal SPEKTRUM. Vol.2. 24-30

[6] Kamalsyah. 2015. LTE Drive Test Parameters.https://www.slideshare.net/ka malsyah/lte-drive-test-parameters. Diakses tanggal 13 Juli 2017

[7] Hikmaturokhman, Alfin. 2014. "4G LTE Drive Test". 4G Handbook Edisi Bahasa Indonesia. Jakarta : Nulis buku

[8] Kusumo, V.S. 2015. "Analisis Performansi Dan Optimalisasi Coverage Layanan LTE Telkomsel Di Denpasar Bali. E-Journal SPEKTRUM. Vol.2. 12-18 